\title{
Concept of Teacher Leaders and Creation of Friendly Climate in the Classroom: In Secondary Education (High School), in Albania
}

\author{
Arjola Manreka, PhD in Process \\ Counseling and Psychological Services (CAPS), in Campus of \\ University of Tirana and Lecturer in University of Durres
}

\author{
Doi:10.5901/ajis.2015.v4n3s1p322
}

\begin{abstract}
Studies have shown that many people are not satisfied with the condition of the schools, that frequent changes in education reform. These changes have led to changes in organizational role to the school, in modifying the roles of the staff who work in this institution. Thus modified noted the role of teachers, relationship that they have with students. Introducing a new concept for teachers, leadership and style that they use in the relationship with students is a concept that is widely studied. This study is one of many ongoing studies enterprises and other foreign and Albanian. And it aims to address those aspects of the educational institution, which exhibit problematic and should be improved. The main hypothesis of this study: 1. Teachers prevents domineering leadership style (is inversely) with the development of a warm and friendly climate in relation to students. 2. The teacher promotes democratic leadership style (is a positive correlation) with the development of a warm and friendly climate in relation to students. The purpose of this study is to determine the style of leadership that the teacher uses positive or negative influences, to create a friendly climate with students. The sample of this study are students and teachers of three profiled high school, a town on the outskirts of Tirana and two other schools in the urban area of the capital city. The study included 165 subjects who completed a questionnaire and a semi-structured interview methods to prove the hypothesis. The study revealed that students are frustrated by their teacher communication. Also teachers are not open to the opinions of students. An domineering teacher who remains in the framework of traditional teachers, does not create a positive climate with students, and no cooperative relationship with them. Study in these three schools, showed the great need that the teacher was democratic, where students had the opportunity to speak freely and openly about everything, even for problems of concern. Some of the valuable recommendations: Teachers should tell students meet what is expected of them to improve the positive climate of learning. Teacher should be a facilitator, guide, model creative and good at making decisions.
\end{abstract}

Keywords: leadership, education, communication, student-teacher relationship.

\section{Introduction}

The notion of teacher leadership is not new, but recently it has been transformed. In the past, the roles of teachers have been limited in scope. Teachers have served as the team leader, were the school administrator's role in the drafting of curricula, etc. In addition to teaching other roles do extra on their responsibilities. In these roles teachers often served as "representatives" rather than be "leaders" who make a difference (Livingston, 1992). In addition, teacher leadership roles traditionally lacking and there has been a kind of flexibility and requires an ongoing commitment long and requires time and energy. Recently, reports on the status of teacher education have issued strong and compelling plea for different dramatic roles, teachers and raise their professional development (Carnegie, 1986; Holmes 1986). Recognizing teaching centrism, reports emphasize the need for teachers to expand their sphere of influence even in classes that they teach. Advocacy for the professionalism of teachers and expanded leadership roles is based on the understanding that teachers (because they have daily contact with students) are in the best position to make critical decisions about curriculum, establishing a positive climate in class. Moreover, they are better able to implement changes in a full and continuous (Howey, 1988, Livingston, 1992).

We are aware that some groups in school social work or social hierarchy, of course that will appear problematic, and various conflicts. As a researcher in this field my job is to know how the school operates and how accomplished cooperation between different social groups working in the school. After numerous studies often by level of degree that respect social status at school can lead to a situation of discrimination against groups that have low social status. School hierarchy being a known and functional process in school, often during the application may be confused by different social groups. So teachers may sometimes require the utmost respect artificially their students. But this really respect the environment unearned school is placed in artificial street action as a result of the school hierarchy. And thus gradually 
brought into the theme and in the course of this study, where teachers have a higher social hierarchy than their students, so in a certain way are the leader of a group with low social status. And in this study we will see different teachers with leadership styles and different relationship based on teacher leadership.

A valuable application for defining the role of the teacher is his ability or rather the work it does for the creation, maintenance and implementation of class operation. It is known that it is not the same thing as to communicate with a group of individuals, or to cooperate with the whole class, where collective productivity, without doubt, is higher. If teachers deliberately focus more than they like to a group, some individuals, it is likely to lose control on the other side of the group, which brings confusion in class efficiency and declining teaching and educational activity. Setting right the normal communication in the classroom increases the more cooperation and interest of all adolescents for high performance. This way of communicating positive pressure exercises to each student to move at the pace of others. Relations open, clear and student teachers downright adolescent influences significantly reduce the level of mistrust and create favorable climate of understanding.

\section{Objectives and Assumptions of the Study}

\section{The purpose of the work:}

The purpose of this study is to determine the style of leadership that the teacher uses in class affects in creating a certain climate in the classroom. It is therefore important to understand the concept of leadership, leadership styles, the climate in the classroom.

Scientific tasks of this study focus on the following aspects:

1. Identify the main characteristics of teacher leadership style, that make a teaching process productive and enjoyable for students.

2. Identify what qualities of leadership, develop or hinder the process of teaching and education of students.

3. Identify whether the changes The relationship teacher - student, if different leadership style of the teacher.

4. To find out if there are connections between leadership style and enjoyment to the class.

The main hypothesis of this study:

1. Teachers prevents domineering leadership style (is inversely) with the development of a warm and friendly climate in relation to students.

2. The teacher promotes democratic leadership style (is a positive correlation) with the development of awarm and friendly climate in relation to students.

Here we will have in mind the kind of leadership style is an independent variable, because if we will try to manipulate with The relationship will change. Also it should be noted that during the discussion will emerge demographic factors such as age sex, years of work experience, etc., which will be neutral variables, but they have their importance in the process of discussion. Leadership style means some features and important factors such as: cooperation, communication, respect, flexibility, responsibility, tolerance. Therefore our analysis on this topic would make such a division based on these factors.

\section{Methodology Used}

To conduct the study were selected two instruments that are very important. Because their aims through the collection of information necessary to achieve the purpose and verification of hypotheses. The study followed several steps that make it simple meaning by the reader:

The first step is to recognize and review of literature on the topic. It reads existing studies on leadership in general, and its kind of styles in particular.Most of them deal with the factors that influence this communication and other independent variables such as stress, the inability of teachers, mosnxënia by students, age, gender. Some of these variables were available for AlbaniaJoining Based on this, it was thought and conceived the application of such a study in three schools, a town on the outskirts of Tirana and two other schools in the urban area of the capital city. Sample selection was made randomly. The study has a limited extension which means that it can not be generalized data.

To verify information gathered from the survey hypotheses and interviewing 165 students and teachers of the three schools. This was accomplished through the completion of two questionnaires (teachers and students), and a semistructured interview with teachers.

Ethical considerations and confidentiality were released early. Each subject was free to accept or refuse the interview. The study tried to include as many factors and elements that were valid and reliable, but also considering that 
their studies have margin of error and little elements that weaken it. Interpretation of the results of the study was limited in the data collected from the sample selected.

Leadership in itself means and exercise his power to someone else. But this sentence is a further continuation because exercise power means authority.

LEADER Lipman'1, (1998) Behold the word characteristics:

L- Listen and talk to everyone. Search feedback (feedback information), by all students, not only the best students or to distinguish the class.

E- Enthusiasm. If teachers are passionate about labor issues, will radiate enthusiasm and students. A positive and optimistic attitude will enable to make the task more effective and more fun.

An (A) - Action and goals are important, but providing a comprehensive action plan will be easier to explain how to achieve the goals. Be creative and take risks in order to find new ways of achieving these goals.

D (Dependability) Safety. Students should be able to trust the teacher leader, whom they see a model that preserves confidentiality and ethical principles.

E (Educated) The teacher should have a good understanding of the dynamics of the students' school work and have about as many different extracurricular organizations regarding students. A teacher leader must lead by example in the classroom.

$\mathbf{R}$ (Results) Results of motivation to keep lasting and positive relationship with the students.

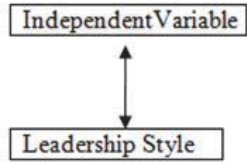

\begin{tabular}{|l|}
\hline Dependent variable \\
\hline $\begin{array}{l}\text { Warm climate and } \\
\text { friendly with students }\end{array}$ \\
\hline
\end{tabular}

Teachers typically have focused their career satisfaction in terms of their ability to be of service to others and make a difference in the lives of their students (McLaughlin \& Lee, 1988). Similarly, teacher leadership considerations are based on their desire to improve the quality of teaching and learning for all students, and to create a friendly and positive atmosphere in the classroom. Studies have shown that teachers do not agree with the traditional definition of leadership "higher authority" positions or "superior" within the organizational hierarchy (Devaney, 1987). Instead, teachers have seen leadership as a joint effort, a "banding together" with other teachers to promote professional development and growth and the improvement of educational services, as well as their relationship with students (Troen \& Boles, 1992).Mësuesit tani janë duke shërbyer si kolegët kërkimore, duke punuar si këshilltar-mentorë të mësimdhënësve të rinj, dhe duke lehtësuar aktivitetet e zhvillimit profesional. Mësuesit gjithashtu veprojnë si anëtarë të ekipeve drejtuese të bazuara në shkollë, ekipeve mbështetëse mësimore dhe udhëheqësit e përpjekjeve të ndryshimit (Livingston, 1992).

\section{The Types and Styles of Leadership}

Its behavior towards subordinates or group leaders to achieve the objectives set, or better known as leadership style varies from one leader to another, and these are:

- Autocratic style (Authoritarian) leadership

The domineering style, based on the assumptions of the theory " $X$ " to McGregory-to human nature not only seeking the opinion of subordinates, but let them a very limited field of action to influence decision-making. Autocratic style (authoritarian) is characterized by the preference to maintain a minimum level of conflict and creativity as well as strict supervision of subordinates, whose motivation is done through fear and incentives. This kind of leader gives orders, is cool with focus group members and so exclusive in the performance.

- Democratic style (or participants) leadership

Democratic style of leadership is based on the theory "Y" to McGregory-t or in theory "Z" to W.Ouchi's, human nature. Democratic leader shares his authority with subordinates, take into account their views and opinions and encourage them to be active in the decision-making process. Considered as a supporter of this style all those individuals

${ }^{1}$ Lipman, P (1998). Academic enrichment through students leadership and community outreach. Retrieved January 3, 2006 from www.gmu.edu 
who do not carry anything without interaction with subordinates or who do not make decisions without prior consultation with them. Although this style gives people a lot of pleasure in work and encourage them to cooperate with higher efficiency, it can not say with certainty whether the decisions made in this way are the best. Recent studies, indeed, cast a shadow over this issue because of the influence of environmental factors and argue that, if the leaders of what lean more participation by workers, then their productivity tends to decrease.

- Liberal style ("laissez-faire")

Liberal style is based on a very limited use of power, leaving a large subordinates in their freedom. Leaders define some very broad limits and allow subordinates to set their own objectives as well as their manner of implementation, thereby playing a role in helping more than superior. This attitude means that they provide proper information subordinates serve as the group's contact with the outside. Liberal leader applying style makes little effort to develop his subordinates or to meet the requirements that they have. As for the democratic style, here support the theory "Y" or "Z" and supporters of these styles prefer to conduct more school.

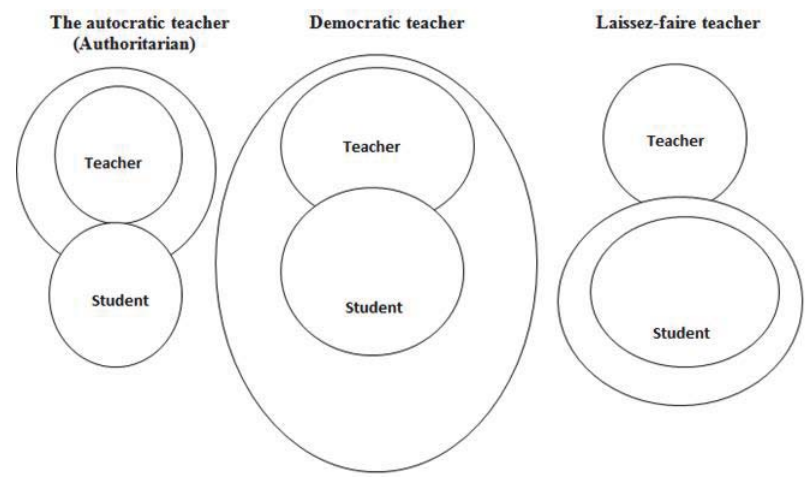

In addition to the terms of his leadership and styles, as we noted above we will try to share the leadership of teachers in some factors such as; communication with students, cooperation, respect, flexibility, tolerance, accountability, etc.

And first to achieve and create a relationship of communication must exist.

Communication is any process in which people share information, ideas and feelings. In his work, "The art of teaching", Flinders (1989), concluded that a professional teacher uses skills such as language and gestures to communicate messages, discovering the beauty, drama and putting students in roles, promoting continued student motivation to learn, etc. He suggested various aspects of professional teaching, and one of these was the communication aspects. According to him, the communication goes beyond speaking or writing, including language of gestures, eye contact, voice intonation, etc.. The effect of these non-verbal reactions to carry the message is conditioned by showing care for students.

Studies currently available on the multidimensional role education institution, have highlighted the fact that this institution has in its composition of certain groups of people who work together, through the exercise of a social status in the school hierarchy. But it also creates division hierarchy of groups working together in school. Who are these groups?

The group with higher status, are headteachers. After this group comes the social status of teachers and students he finally. However, experience has shown that this kind of hierarchy creates a precarious situation, especially discriminating between teachers and students. From the interaction of these groups with different statuses, it can be moved from a rigid and problematic communication towards a liberal and chaotic communication. The process of teaching requires active communication and the establishment of bilateral relations between groups that have different statuses in school.If further ban teacher-student relationship and type of communication, it is seen that there is a clear justification. Teachers having a higher social status than the students, can artificially require the utmost respect from students. So today in schools, we are carefully observe, since the plurality of the teachers, few of them really enjoy the respect of students. The rest of the teachers do not enjoy the same degree of respect, but impose respect for their status and authoritative stance and their distant students. 


\section{Communication Styles}

Human communication is more complex than it seems, if maintained in view of that it appears with different styles, they can be:

a) Free style and natural

b) Official Style

c) Authoritarian style

d) Dictatorial style

e) Eonformist style

f) Democratic style

g) Artistic style, etc.

There are also many other styles that appear in communication. These styles are a way of communicating, which is conditioned by psychological nature or type of entity that communicates, his social position, or state official, conditions, circumstances, or a particular context, such as a school. Communicating style stems from communication strategy, but should not be regarded as similar.

\section{Results}

The study found that the teacher-student ratio, there is a negative correlation between authoritarian style of teachers and creating a warm and friendly climate in this report.

The study also found that the ratio between male teachers and students gender difference was not a teacher. The relationship of cooperation and the same was Notwithstanding this fact.
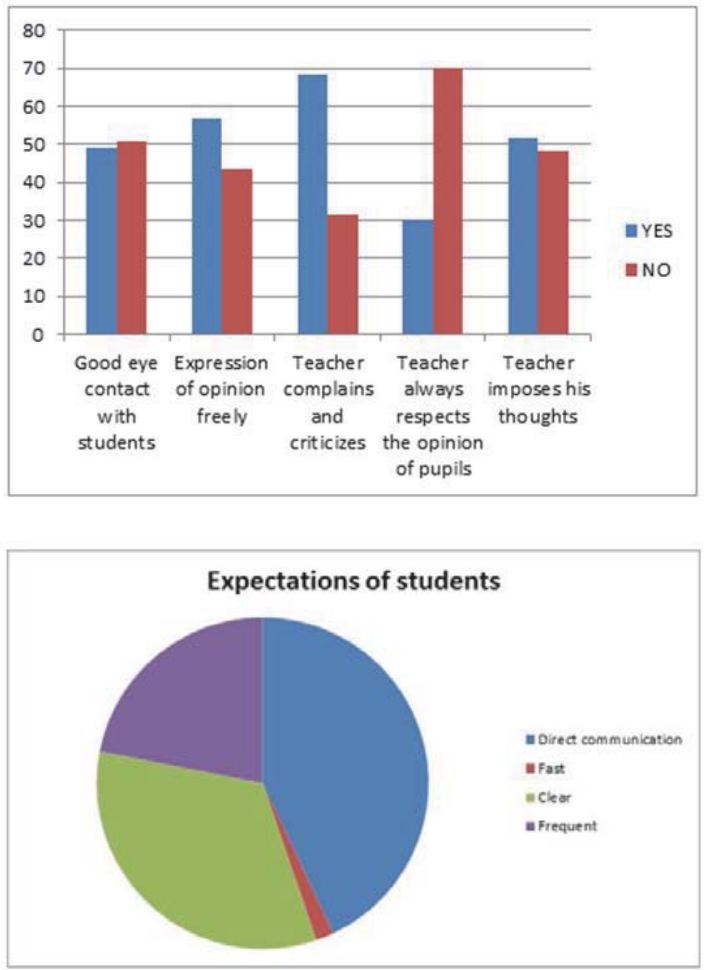


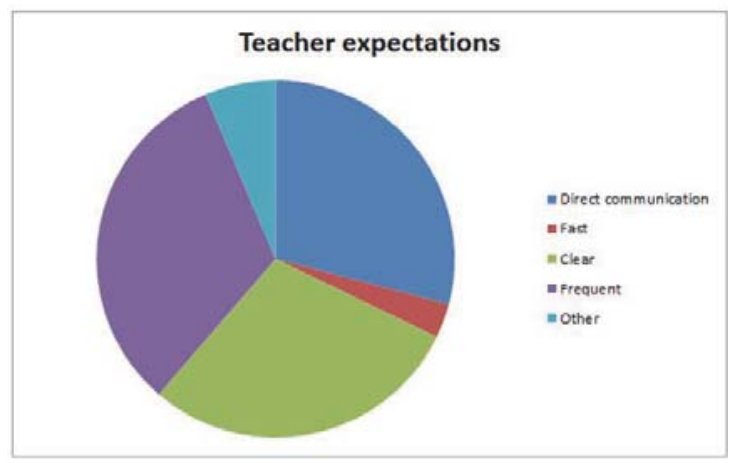

So, the teacher with the democratic leadership style is positively correlated with the development of a warm and friendly climate in relation to students.

From the answers in students showed that their teachers almost all the time, are free and are impatient mood in relation to students. Critics often complain and make their students, and other elements that confirm that their teachers rarely are friendly with their students.

\section{Discussion}

Teacher-student relationship is one of the most important reports of the process of education in the school institution. This relationship is influenced by many factors, external and internal. Adolescent educated teacher to assess not only by age, but by the role it plays in this institution, then at school. Teacher-student ratio realized straight, when the teacher has sufficient personal professional skills. The school environment is privileged territory where social analyzes and develops the mental process of teenager student who pursues his lifelong. So when the school does not function well, no damage something at the individual, but mainly socially, because not encourage desired behaviors systems.

This study will show us and will extend us more perspective on the status, leadership style, some specific types of communication, cooperation, tolerance, and many other factors in this relationship "giant" of teachers and students. The main hypothesis of the study was whether the teacher with authoritarian leadership style back the creation and development of a warm and friendly climate in relation to students. This hypothesis argue with previous studies in the literature, but also the concepts and definitions. And what is it that really happens, to make an analysis of this hypothesis? As mentioned in the introduction or in the literature of the subject itself of the institution of the school hierarchy makes you think and throw multiple hypotheses for this connection status and interdependence between teachers and students. By comparing the study that is cited in the literature review chapter, it noted that teachers having a higher social status than the students, can artificially require the utmost respect from students. So today in schools, we are carefully observe, since the plurality of the teachers, few of them really enjoy the respect of students. The rest of the teachers do not enjoy the same degree of respect, but impose respect for their status and authoritative stance and their distant students. So, according to this study and other studies psychopedagogic, it indicated that somehow, imposed i'u student teachers, unconsciously, as a result of higher status they enjoy. Even in our study was observed this phenomenon and attitude of this hypothesis. For the fulfillment of the instrument they revealed that students are frustrated by their teacher communication. And that was observed in the percentage of what they had alternatives very unhappy, and unhappy. But students from the completion of the questionnaire out another fact, that a great part of them feel that their teachers are not open to the opinions of students. But even by their teachers they had an equal percentage, the answer provided by this question. Half of them said they are open to the opinions of students and the other half not, are not open.

Communication is an element that shows the leadership style of the teacher, but also a way of establishing friendly relations with students. And the question on the creation of a climate and atmosphere in the classroom when students communicate openly and freely, again a large percentage stated that the climate is calm, and a slightly higher percentage said that the climate is friendly.

Another element where students bring their authoritarian teachers, is cooperation in this relationship. How strong is this cooperation?

The students claim that teachers impose their student opinions. But this assertion true results when students were 
asked their teachers promptly implement rules regardless of student opinion. So, to take a new initiative or project, the teacher sets itself, and not the opinion of their students, although this project may affect a touch and the students. But besides these little facts mentioned above, teachers are neither flexible in relation to the students, so are not tolerant. This is seen in the question that has become their pupils if teachers tolerate a joke, or particle of humor, if you see that you are tired and unfocused; and their answer was never true. This means that their teachers are strict and inflexible. But even by their teachers claim that making jokes, meant to create "Your hands," an unbearable situation in the classroom. And occasionally true alternative, answered most of the teachers.

A pretty interesting element emerges, when students are asked directly if their teachers are friendly or not. A large percentage of cases stating that it is true. But in this question there is a difference between schools. Bathore school, more students stated that their teachers are friendly. While the two other schools (Partizani and Çajupi), stated that with cases or never friendly. Here it is seen that in schools where students and teachers are coming too, so there are a heterogeneous environment and heterogeneous culture, it has greater spirit of cooperation. While the schools that retain somewhat homogeneous and traditionalism of schools being "elite" are not very open, and do not accept more the spirit of change.

A Democrat teacher, then with the Democratic leadership style, has based his work, creating situations as cooperative with his students, but also to students with each other. Faced with the question of whether the teacher punishes the "noise" created in class when he himself has put to work in groups, the students responded that this statement is always true. But even the teachers claim that the case is the thing. claim; "Working in groups, meaning noise and unbearable situation", it belongs to a teacher with authoritarian leadership style.

Are the teachers good listener? A significant percentage of the cases have said that it is true. Which tells us that there are special teachers who can be good listeners, while others do not.As a conclusion, to make a summary of what was said above, the hypothesis that there is a negative correlation between authoritarian leadership style of teachers and developing a warm and friendly climate in relation to the students, was confirmed by this study that is done in three secondary schools in Tirana. What I need to analyze for this finding it is the fact that the Albanian reality there is still the idea of a teacher who is a good professional, good Methodists, has clear objectives and that's teaching. But it lacks the most important personal and individual skills, as a good citizen and as a worthy member of society. Where students will have a model to follow. What is happening in Albania still is the fact that we are not separate ourselves from the idea of teachers before ' 90 , who had all the characteristics of a professional teacher, but there was no humanity in relationship with his students. So it was little cooperation, communication as well. Listening carefully to the students, their problems, good classroom management, teaching organization with interactive methods, all were missing in the teachers completing the picture before ' 90 . And apparently still we inherit this model, which has numerous shortcomings and deficiencies.Teaching is generally regarded as more than fifty percent of fifty percent knowledge and interpersonal skills or communication skills. For a teacher, it is important not only give a qualitative learning, but also important is the way he delivers it.Students Are the future of every nation. This is why the role of teachers is so important for society. This is a teacher by generations of young people are deeply influenced. Overall improvement in a student can be expected when communication skills for teachers is given due importance. Thus, it is important that communication skills to become an important component of teachers' professional competence. The teacher promotes democratic leadership style (is a positive correlation) with the development of a warm and friendly climate in relation to students. If the teacher with authoritarian leadership style back the creation and development of a warm and friendly climate in relation to students

\section{Recommendations}

Recommendations for future research:

1- The results of this study, it is necessary to become even more such studies and scientific research in the field of leadership in secondary education, but also in all the categories and levels of education. To see the connection that exists between leadership style and report creation with students.

2- The researcher also should be mentioned that due to limited resources, could include only two variables. Other researchers recommended that seed you include dimensions and other sources also, to increase the effectiveness of the study.

3- Also it is recommended to choose a champion or large populations, to enable generalization of research data.

4- The study as we have described above, has limitations because it dealt only with secondary education, and recommendation that can be given to young researchers would be; They can also extend the search to the highest levels, ie higher education, or basic education. 
5- This study is particularly important because in reality carried Albanian and has not been explored much.

Recommendations for practitioners (teachers), and relevant instances:

Discussion in class begins at the moment when students ask questions and when a student is responsible for what another student said. It is a mixture of teacher-student explanations, the exchange of views and questions.

When the teacher involved in this kind of communication that should contribute to strengthening the fluency of thought and the development of what is said. The teacher should remember that one of the reasons the discussion in class is to give students a chance to develop and express their ideas. This requires stirring and tolerance. In this climate, it is allowed to express the notions incorrect, even wrong (to be sure that mistakes are made more apparent in the discussion, rather than interrupting it abruptly).

1- This is one of the recommendations that should be done teachers, to promote the creation of this climate of discussion in the classroom with their students, because in this way mitigate the relations between them, and made the facilities and favorable.

2- The basis of this study suggested that teachers should use different styles of leadership that best suits the situation.

3- Teachers also need to ensure recognition of the students in decision-making and creating different policies for student class service.

4- Teachers should be show students what is expected of them to improve the positive climate of learning.

5- Teachers should take into account their individual differences, and individual student differences and take into account students' satisfaction.

6- The teacher should be a facilitator, guide, and model good creative decision making.

7- Training teachers from different teams as external professionals as well as internal. To receive information on the most modern methods, and more recent.

8- The function well in school psychological services, where both parties are advised to different problems in this relationship.

9- individual research done by the teachers, the other mode of communication, cooperation, leadership styles. What happens and what the effect is when a student is led by an authoritarian teacher? The teachers reflect on the climate they create in class, whether it is favorable or not?

10- These questions should be part of teacher reflection, and his personal research.

Exchange of experiences 10 teachers from different schools. So be meetings with other school teachers, and to share experiences.

11- Discuss with students which methods they would like practiced in the classroom, and it automatically improves teacher-student relationship, because the opinion of the latter.

12- Ministry of Education and Science to offer training and seminars for teachers and abroad, to view and share other types of teaching methods and experiences.

\section{References}

Arendt, H: Through the past and present (Nëpërmjet të shkuarës dhe të sotmes), Tiranë 1998

Bennis, W. (1989) On Becoming a Leader, Addison Wesley, New York, 1989

Como, B: Communication psychology (Psikologji Komunikimi) (Refleksione dhe Ligjërata), Tiranë, 2001

Dervishi, Z: Cohabitation conflicts demons (Bashkëjetesë me demonët e konflikteve), Tiranë, 2002, fq. 115 - 182

Dervishi, Z: Flirte with injuries (Flirte me plagët), Tiranë, 2003

Dervishi, Z: Insights crossed the sea (Vështrime të kryqëzuara në det), Tiranë 2003

Dragoti, E: Social psychology (Psikologjia Sociale), Tiranë, 1999

Fullan, M: Forces of change; (Penetration into the depths of educational reform) (Forcat e ndryshimit); (Depërtim në thellësitë e reformës arsimore), Tiranë, 2010. CDE, Center of Democratic Education ( Qendra për Arsim Demokratik)

Fullan, M: New Meaning of Educational Change (Kuptimi i ri i ndryshimit në Arsim), Tiranë, 2001. CDE ( Qendra për Arsim Demokratik)

Fullan, M (1998).Leadership for the 21st century: Breaking the bonds of dependency.Educational leadership.vol 55

Karaj, Th: Management class (Applied Psychology in teaching) (Menaxhimi i klasës, Psikologji e zbatuar në mësimdhënie), Tiranë, 2008, fq. $68-71$

Shehu, A: Communication psychology (Psikologji Komunikimi), Tiranë, 2005

Musai, B: Educational Psychology (Psikologji Edukimi), Tiranë 1999

Orhani, Z: The psychology of motivation and motivation in learning (Psikologjia e motivacionit dhe motivimi gjatë të nxënit), Tiranë, 2006

Orhani, Z: Cognitive psychology (Psikologjia Kognitive), Tiranë 1999

Human Development Center (Qendra e Zhvillimeve Humane): Materials to help school psychologists (Materiale në ndihmë të 
psikologëve shkollorë), Tiranë, 2008

Peck, S: The way in which rarely go (Book for the edification) (Rruga në të cilën rrallë shkohet ( Libër për ngritjen shpirtërore), Tiranë 2002

Hollander, E.P ( 1985); Conformity, status, and idiosyncrasy credit. Psycological Review, 65, 117-127

Leadership Handbook, LGP/UNDP, 2004

Lipman, P (1998). Academic enrichment through students leadership and community outreach. Retrieved January 3, 2006 from www.gmu.edu

Gardner, Leading Minds, An Anatomy of Leadership, 2000). 13

O'Connor, C. (1996) Successful leadership, Hodder \& Stoughton, 1996

Social Artistry Fieldbook, Book 1, Developing your inner capacities, UNDP, 2004

UNDAF, Appreciative Inquiry, UNDP 2004

http://www.nwlink.com/ donclark/leader/leadmet.html

http://www.cmer.org/clearinghouse/leader/leaderrp.pdf

UNDP Local Governance Program (Programi i Qeverisjes Vendore), Tirana 20052 